\title{
Prospek dan Tantangan Dakwah Bil Qalam sebagai Metode Komunikasi Dakwah
}

\author{
Rini Fitria \\ Komunikasi dan Penyiaran Islam \\ Institut Agama Islam Negeri Bengkulu \\ Rafinita Aditia \\ Komunikasi dan Penyiaran Islam \\ Institut Agama Islam Negeri Bengkulu
}

Korespodensi dengan Penulis:

Rini Fitria, Telp: 081367548253

E-mail: rini@gmail.com

Keywords:

$D a^{\prime}$ wah bil

Qolam, $D a^{\prime}$ wah

Communication,

Da'wah Method.

\section{Kata kunci:}

Dakwah Bil

Qalam,

Komunikasi

Dakwah, Metode

Dakwah.

\section{Abstract}

Communication is a process that is absolutely owned by every human being both verbally or non-verbally. One form of communication is called propaganda communication. Da'wah communication is carried out for the purpose of inviting humanity to the amar ma'ruf nahi munkar. For the purpose of the desired da'wah communication to be achieved, a communicator must be able to choose the method to be used. Da'wah bil qalam as a method of da'wah communication is able to overcome the weaknesses of da'wah which is only done verbally. This method also provides the opportunity for the mad'u to choose the message of preaching in accordance with their abilities and interests so that the purpose of missionary communication is effective and efficient.

\footnotetext{
Abstrak

Komunikasi merupakan proses yang mutlak dimiliki setiap individu baik secara verbal atau nonverbal. Salah satu bentuk komunikasi disebut dengan komunikasi dakwah. Komunikasi Dakwah dilakukan untuk bertujuan mengajak manusia kepada amar ma'ruf nahi munkar. Agar tujuan dari komunikasi dakwah yang diinginkan dapat tercapai, seorang komunikator harus mampu memilih metode yang akan digunakan. Dakwah Bil Qalam sebagai sebuah metode komunikasi dakwah mampu mengatasi kelemahan dakwah yang hanya dilakukan dengan lisan. Metode ini juga memberikan kesempatan para mad'u untuk bisa menentukan message dari dakwah dakwah sesuai kemampuan dan kepentingannya sehingga tujuan komunikasi dakwah efektif dan efisien.
} 


\section{PENDAHULUAN}

Sebagai makhluk sosial, manusia tidak akan bisa terlepas dari proses komunikasi. Komunikasi ialah suatu hal yang pasti dimiliki oleh setiap individu. Ada banyak sekali bentuk komunikasi yang ada, salah satunya yaitu Komunikasi Dakwah. Komunikasi Dakwah merupakan semua bentuk komunikasi yang berkaitan dengan pesan seruan ke jalan Allah SWT atau bentuk mengajak berbuat baik dan meninggalkan keburukan. ${ }^{1}$ Komunikasi Dakwah dilakukan untuk mencapai suatu tujuan, yaitu mengajak manusia kepada amar ma'ruf nahi munkar. Agar tujuan dari komunikasi dakwah yang diinginkan dapat tercapai, seorang komunikator harus mampu memilih metode mana yang akan digunakan.

Metode dalam Komunikasi Dakwah yang digunakan harus mampu disesuaikan dengan keadaan komunikan. Di zaman modern yang dikelilingi teknologi canggih seperti sekarang, Komunikasi Dakwah ini tentu tidak cukup jika hanya dilakukan dengan lisan. Keberadaannya mesti didudukung dengan metode lain yang mampu menjadi penghubung antara komunikator dengan komunikan dengan jangkauan yang lebih luas. Hal ini dapat diperoleh jika komunikasi dakwah juga dilakukan dengan metode berupa Dakwah Bil Qalam.

Dakwah Bil Qalam sebagai metode dalam berdakwah membantu memperbaiki kelemahan dakwah yang hanya dilakukan dengan lisan. Dakwah bil lisan yang mempunyai kekurangan pada jangkauan dan waktu, dapat dipenuhi melalui dakwah Bil Qalam. Dakwah bil Qalam memberikan peluang komunikan dalam suatu komunikasi dakwah menuangkan gagasan dan ide secara utuh lewat tulisan. Sehingga efek yang ditimbulkan dari suatu komunikasi dakwah akan bersesuaian dengan yang diharapkan.

\section{METODE}

Metode pada penulisan artikel ini menggunakan metode studi kepustakan. Menurut Mardelis penelitian kepustakaan atau library reasearch merupakan penelitian yang menggunakan telaah dan kajian kepustakaan atau konsep-konsep teoritis. ${ }^{2}$ Ini dilakukan dengan cara menganalisis konsep-konsep, referensi atau sumber yang berkaitan dengan gagasan dan permasalahan yang diangkat dalam tulisan. Selanjutnya hasil dari telaah terhadap konsep hasil bacaan dianalisis, diambil inti sarinya dan dilakukan proses reduksi hasil pengkajian referensi data dan mengkorelasikannya dengan gagasan dan konsep dari referensi.

\footnotetext{
${ }^{1}$ Wahyu Ilaihi, “Komunikasi Dakwah”, (Bandung: Remaja Rosdakarya, 2013), hlm. 17.

2 Mardelis. "Metode Penelitian Suatu Pendekatan Proposal", (Jakarta: Bumi Aksara, 2004), hlm. 28.
} 


\section{HASIL DAN PEMBAHASAN}

\section{Memaknai Komunikasi Dakwah}

Kata dakwah adalah bentuk masdar dari اعد - واعدي - مة عد (da'a-yad'u-da'watan) yang memiliki arti sangat beragam. Maknanya antara lain diartikan sebagai panggilan, seruan permohonan, aktifitas misionari, dan propaganda. ${ }^{3}$ Berdasarkan arti dakwah ini, dapat pula ditarik pemahaman bahwa dakwah merupakan suatu kegiatan yang dijalankan oleh siapa pun dalam konteks mengajak, menyeru, memanggil, atau memohon, tanpa memilah-milih tentang asal-usul terkait agama atau ras. ${ }^{4}$

Dakwah dapat diartikan sebagai upaya yang dilakukan secara terus-menerus untuk memberikan perubahan pada manusia yang meliputi pikiran (fikrah), perasaan (syu'ur), dan tingkah laku (suluk) yang kemudian menuntun mereka kepada jalan Allah (Islam), sampai akhirnya mampu membentuk masyarakat yang Islami (al-mujtama' al-Islami). Setidaknya, ada empat aktivitas utama dakwah, diantaranya mengingatkan orang akan nilai-nilai kebenaran dan keadilan dengan lisan, menyebarluaskan prinsip Islam melalui karya tulisan, memberikan panduan keteladanan terkait perilaku (akhlak) yang baik, dan bersifat tegas terhadap kemampuan fisik, harta, dan jiwa dalam menegakkan prinsip-prinsip Ilahi. ${ }^{5}$

Secara umum, dakwah adalah ajakan atau seruan kepada hal baik agar individu mampu menjadi lebih baik. Dakwah berisikan ide menyangkut progresivitas, sebuah proses tanpa henti untuk mengajak individu kepada yang baik dan yang lebih baik dalam mewujudkan tujuan dakwah tersebut. Namun, dakwah pada sisi prakteknya meliputi kegiatan mentransformasikan nilai-nilai agama yang mempunyai arti krusial dan berperan langsung dalam membentuk persepsi umat terhadap berbagai nilai kehidupan. ${ }^{6}$

Ada banyak sekali definisi tentang dakwah menurut para tokoh dan pemikir Islam. Dalam buku Metode Dakwah karya Munzier Suparta dan Harjani Hefni, Syekh Ali Mahfudz mengemukakan bahwa dakwah adalah kegiatan menyeru manusia agar mengerjakan kebajikan serta mengikuti arahan yang benar, mengajak mereka melakukan hal-hal baik dan melarang mereka dari prilaku yang buruk supaya mereka memperoleh kebahagiaan dunia serta akhirat. ${ }^{7}$

Quraish Shihab mengartikan dakwah sebagai ajakan atau seruang menuju keinsafan, atau upaya mengubah keadaan yang tidak baik kepada keadaan yang lebih baik serta sempurna

\footnotetext{
${ }^{3}$ Siti Muriah, "Metodologi Dakwah Kontemporer", (Yogyakarta: Mitra Pustaka. 2000), hlm. 1-2.

${ }^{4}$ Komarudin, dkk. "Dakwah dan Konseling Islam", (Semarang: PT. Pustaka Rizki Putra, 2008), hlm. 1.

${ }^{5}$ Asep Syamsul M. Romli, "Jurnalistik Dakwah: Visi dan Misi Dakwah Bil Qalam", (Bandung: Remaja Rosdakarya, 2003), hlm. 6.

${ }^{6}$ Wahyu Ilaihi, Komunikasi Dakwah.. hlm. 24.

7 Munzier Suparta dan Harjani Hefni, "Metode Dakwah", (Jakarta: Kencana, 2003), hlm. 7.
} 
baik terhadap pribadi ataupun masyarakat yang berada di suatu lingkungan. ${ }^{8}$ Moh. Ali Aziz dan Abu Bakar Zakaria juga mengemukakan bahwa dakwah adalah upaya yang dilakukan para pemuka agama dan orang-orang yang mempunyai pengetahuan agama Islam untuk memngajar pada khalayak ramai sesuai kemampuan yang dimiliki tentang hal yang mereka perlukan dalam urusan di dunia dan keagamaan. ${ }^{9}$ Kemudian, H.S.M Nasaruddin Latif memberikan definisi dakwah sebagai upaya atau kegiatan dengan lisan maupun tulisan dan lain sebagainya, yang sifatnya mengajak, menyeru, memanggil manusia untuk taat dan beriman kepada Allah SWT, sesuai pedoman akidah, syari'at, dan akhlak Islamiyyah. ${ }^{10}$

Dakwah memiliki beberapa unsur, diantaranya $d a^{\prime} i$ atau subyek pelaku dakwah, maddah al-da'wah atau materi yang disampaikan dalam berdakwah, thariqah atau manhaj al-dakwah atau metode dakwah, wasilah atau sarana/wahana berdakwah, ghayah al-da'wah atau tujuan yang hendak dicapai dalam dakwah.11 Dapat diartikan pula bahwa dakwah merupakan suatu kegiatan yang mengajak dan menyeru kepada agama Allah SWT, yang meliputi wilayah yang luas dalam semua aspek kehidupan. Dakwah memiliki ragam metode, bentuk, pesan, media, pelaku, serta mitra dakwah. Dakwah dilakukan guna mememperoleh tujuan tertentu. Agar tujuan dakwah dapat tercapai, dibutuhkan metode yang tepat. Salah satunya ialah metode dakwah Bil Qalam.

Pengertian Dakwah bil qalam dapat dirujuk dari asal bahasanya, yaitu bahasa Arab. Dakwah bil qalam jika ditulis sesuai gramatikal bahasa Arab, maka akan ditulis ad-da'wah bi alqalam, terdiri dari dua kata yaitu, da'wah dan qalam. Dakwah Bil Qalam yaitu suatu upaya menyeru manusia menggunakan cara yang bijaksana kepada jalan yang benar sesuai dengan perintah Allah Swt melalui seni tulisan. Pengertian dakwah Bil Qalam menurut Suf Kasman yang dikutip dari Tasfir Departemen Agama RI menjelaskan definisi dakwah Bil Qalam, ialah menyeru manusia secara bijaksana ke jalan yang benar sesuai dengan perintah Allah Swt, melalui seni tulisan. ${ }^{12}$ Penggunaan nama "qalam" merujuk kepada firman Allah SWT Q.S alQalam ayat 1 yakni

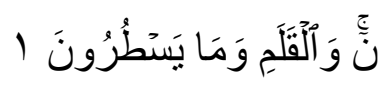

"Nun, demi kalam dan apa yang mereka tulis."

Dakwah Bil Qalam ini telah diaplikasikan pada zaman Rasulullah. Karena pada saat itu, tradisi tulis menulis sudah berkembang. Terbukti ketika Rasulullah SAW menerima wahyu, hlm. 9

8 dalam Munir dan Wahyu Ilaihi, “Manajemen Dakwah”, (Jakarta: Kencana, 2006), hlm. 20.

${ }_{9}^{9}$ Moh. Ali Aziz, “Ilmu Dakwah”, (Jakarta: Kencana, 2004), hlm. 11.

10 dalam Rosyad Sholeh, "Manajemen Dakwah Islam", (Yogyakarta: Suara Muhammadiyah, 2010),

${ }^{11}$ Komarudin, dkk. Dakwah dan Konseling Islam... hlm. 4

12 Abdul Wachid, “Wacana Dakwah Kontemporer", (Yogyakarta: Pustaka Pelajar, 2005), hal. 223. 
beliau langsung meminta para sahabat yang mempunyai kemampuan untuk menulis wahyu yang diterimanya. Padahal di zaman itu secara teknis sangat susah untuk bisa melaksanakan kegiatan tulis-menulis dikarenakan sarana yang belum tersedia seperti kertas dan alat tulis lainnya, disamping budaya yang kurang mendukung. Namun para sahabat tetap berusaha untuk mampu melakukannya. ${ }^{13}$

Ali bin Abi Thalib pernah berkata, "Tulisan ialah taman para ulama,". Melalui seni tulisan para ulama "mengabadikan" dan menyebarluaskan pemikiran serta pandangan keislamannya. Dakwah Bil Qalam yang sudah dilakukan para ulama salaf serta cendekiawan muslim pada zaman dahulu, menciptakan sejumlah "Kitab Kuning". Mungkin, apabila mereka tidak menuangkan dalam tulisan, pemikiran para ulama dan mujtahid akan susah untuk dipelajari serta diketahui pada zaman sekarang ini. Metode menggunakan karya tulis ialah buah dari keterampilan tangan ketika memberikan pesan dakwah. ${ }^{4}$ Peradaban dunia akan hilang tak berbekas ketika karya tulis yang berisi dakwah (Dakwah bil Lisan), tidak dipublikasikan. Seperti ketika kita memahami Al-Qur'an, hadits, fiqih para madzhab dari tulisan yang dipublikasikan.

Bentuk dakwah Dakwah Bil Qalam terbagi menjadi melalui tulisan dan melalui media cetak. Dakwah Bil Qalam melalui tulisan dilakukan dengan cara dimana para penulis (ulama, kyai, dan para pengarang kitab) menyajikan dalam bentuk seperti kitab kuning dan berbagai kitab karangan untuk dipelajari dan di kaji oleh para pelajar, santri maupun yang lainya. Mengingat wahyu yang diturunkan kepada Rasulullah SAW yang memerintahkan untuk "Bacalah", maka diadakanya suatu perintah untuk menulis sesuatu tentang Islam dan hukumhukum yang ada dalam Al-Quran supaya dapat di baca para khalayak yang luas. ${ }^{15}$

Sedangkan dakwah Bil Qalam melalui media cetak, ialah suatu bentuk penyajian dakwah Bil Qalam dengan bahasa dan kemasan yang mudah untuk dipahami dalam suatu media cetak. Seperti halnya buku, koran, majalah, tabloid, benner, pamflet, stiker dan kaos yang mengandung unsur Islam sehingga dapat diterima dengan mudah kepada pembacanya.

Dakwah Bil Qalam memiliki efisiensi dalam kegiatanpenyampaian kepada para khalayak luas. Para ulama maupun pemimpin menggunakan ilmu jurnalistik untuk mendesain dengan sedemikian rupa sampai akhirnya pembaca suatu buku, surat kabar, majalah, maupun karya tulis lainnya mampu dimasuki unsur Islam maupun dakwah berupa tulisan. Bagaimanapun dinamikanya, dakwah melalui tulisan tetaplah sebuah tantangan untuk para da'i, tulisan seolah menjadi suatu metode serta media yang lebih mampu bertahan jika dibandingkan dengan

\footnotetext{
13 Ibid., hlm. 223.

14 Moh. Ali Aziz, Ilmu Dakwah... hlm. 374.

15 Asep Syamsul M. Romli, “Jurnalistik Dakwah: Visi dan Misi... hlm. 44.
} 
dakwah secara lisan. ${ }^{16}$ Dakwah bil Lisan bukannya harus ditinggalkan, namun sebaliknya, kita hanya perlu mengambil satu langkah lagi untuk menulis konsep dakwah yang ingin disampaikan secara lisan menjadi sebuah tulisan sehingga dakwah yang kita jalankan semakin efektif.

\section{Maknai Komunikasi Dakwah}

Kata komunikasi atau communication dalam bahasa Inggris berasal dari kata Latin communis yang memiliki arti "sama", communico, communicatio, atau communicare artinya "membuat sama" (to make common). Istilah pertama (communis) umunya disebut sebagai awal lahirnya kata komunikasi, yang merupakan akar dari kata Latin lainnya yang mirip. Komunikasi memberikan arti bahwa suatu makna, suatu pesan, atau suatu pikiran dianut secara sama. Namun definisi kontemporer menyatakan bahwa komunikasi ialah cara untuk berbagi hal-hal tersebut, seperti dalam kalimat 'Kita berbagi pikiran', 'Kita mendiskusikan maknaI, dan "Kita mengirimkan pesan'. ${ }^{17}$

Secara sederhana komunikasi dapat dipahami sebagai proses penyampaian message dari komunikator kepada komunikan menggunakan suatu media untuk menimbulkan efek agar tercapainya suatu tujuan. Komunikasi merupakan sebuah peristiwa yang berisfat sosial yang terjadi pada saat manusia melakukan interaksi dengan manusia lain. ${ }^{18}$ Disadari bahwa begitu banyak definisi komunikasi, akibat dari kaya dan kompleksitasnya disiplin ilmu komunikasi. Para ahli seringkali memperhatikan fenomena manusia denan kacamata mereka sendiri, bahkan mereka memberikan batasan saat berupaya menjelaskan sebuah fenomena pada orang lain. Seorang ahli dalam bidang komunikasi umumya menggunakan pendekatan yang berbeda dalam menginterpretasikan komunikasi karena nilai-nilai yang mereka miliki juga berbeda. ${ }^{19}$

Syaiful Rohim dalam buku Teori Komunikasi: Perspektif, Ragam, dan Aplikasi menjelaskan bahwa komunikasi merupakan suatu penyampaian informasi kepada orang lain, yang diharapkan dapat dimengerti dan dipahami. Hal tersebut dapat dilihat melalui sebuah sumber yang memberikan pesan pada seorang penerima diiringi dengan upaya mempengaruhi perilaku penerima. Dengan adanya komunikasi dapat memudahkan seseorang dalam

${ }^{16}$ Al-Hasjmy, “Dustur Dakwah dalam Al-Qur'an”, (Jakarta: Bulan Bintang, 1974), hlm. 37.

17 Deddy Mulyana, "Ilmu Komunikasi Suatu Pengantar", (Bandung: Remaja Rosdakarya, 2012), hlm. 46.

18 Jalaluddin Rakhmat, "Psikologi Komunikasi", (Bandung: PT Remaja Rosda Karya, 2017), hlm. 9.

19 Brant D. Ruben dan Lea P. Stewart, "Komunikasi Dan Perilaku Manusia”, (Jakarta: Rajawali Pers, 2013), hlm. 358. 
mengerjakan sesuatu karena mendapat informasi dan arahan yang sudah diterima dengan salah satunya melalui komunikasi. ${ }^{20}$

Onong Uchayana Effendi mengemukakan bahwak komunikasi adalah suatu kegiatan menyampaikan pikiran maupun perasaan daei seseorang (komunikator) kepada orang lain (komunikan). Pikirannya dapat berupa informasi, gagasan, opini, dan lainnya yang muncul dari benaknya. Perasaan dapat berupaya kepastian, keyakinan, kekhawatiran, keragu-raguan, keberanian, kemarahan, kegairahan, dan lainnya yang muncul dari lubuk hati. Komunikasi dapat berhasil ketika pikiran disampaikan melalui perasaan sadar; sebaliknya komunikasi dapat gagal ketika saat menyampaikan pikiran, perasaan tak terkontrol.21

Dapat dikatakan bahwa komunikasi ialah suatu proses penyamapain pesan dari seorang sender kepada komunikan menggunakan metode dan media tertentu sehingga menimbulkan efek yang diinginkan. Apabila dalam pesan yang disampaikan terdapat unsur dakwah, maka komunikasi yang dilakukan dapat pula dikatakan sebagai komunikasi dakwah. Asep Syamsul M. Romli menyatakan bahwa Komunikasi dakwah ialah sutau proses penginformasian tentang Islam yang bertujuan memengaruhi komunikan (objek dakwah, mad'u) agar mempercayai, mengamalkan, mengilmui, membela, dan menyebarkan kebenaran ajaran agama Islam. ${ }^{22}$

Wahyu Ilaihi mendefinisikan komunikasi dakwah proses penyampaian informasi atau pesan berupa message dari seorang maupun sekelompok orang pada seorang ataupun sekelompok orang lainya yang bersumber dari al-qur'an dan hadis dengan tujuan agar mampu mengubah pendapat, sikap, serta perilaku orang lain agar menjadi lebih baik sesuai dengan tuntunan Islam, dengan cara langsung melalui lisan, ataupun tidak langsung dengan menggunakan media. 23

Proses komunikasi dakwah terjadi layaknya proses komunikasi pada umumnya, berawal dari komunikator (da'i) sampai pada umpan balik komunikan (mad'u, objek dakwah). Kegiatan dakwah diawali dari seorang komunikator (sender, pengirim pesan, da'i). Dalam pandangan Islam, setiap Muslim merupakan komunikator dakwah sebab dakwah ialah kewajiban individual bagi tiap Muslim. Komunikator dakwah memilih gagasan berupa materi dakwah (encoding) kemudian diolah menjadi pesan dakwah (message). Pesan itu ditransmisikan melalui sarana (media) yang tersedia untuk nantinya diterima oleh komunikan (penerima pesan, objek hlm. 12

${ }^{20}$ Syaiful Rohim, “Teori Komunikasi: Perspektif, Ragam dan Aplikasi”, (Jakarta: PT Rineka Cipta, 2009),

${ }^{21}$ Onong Uchayana Effendi, "Ilmu Komunikasi Teori dan Praktek", (Bandung: Remaja Rosdakarya, 2017), hlm.11.

22 Asep Syamsul M. Romli, "Komunikasi Dakwah Pendekatan Praktis", (Bandung: Simbiosa Rekatama Media, 2013), hlm. 12.

${ }^{23}$ Wahyu Ilaihi, Komunikasi Dakwah.. hlm. 26. 
dakwah). Selanjutnya komunikan mengartikan simbol-simbol pesan dakwah itu (decoding) kemudian memberikan umpan balik (feedback) atau meresponnya, semisal berupa pemahaman dan pengamalan pesan dakwah yang diterimanya. ${ }^{24}$

\section{Dakwah Bil Qolam sebagai Metode Komunikasi Dakwah}

Menurut bahasa kata metode berasal dari dua kata yaitu "meta" (melalui) dan "hodos" (jalan, cara). Sehingga dapat diartikan bahwa metode atau jalan yang mesti dilewati untuk meraih suatu tujuan. Sumber lain menyebutkan bahwa kata metode berasal dari bahasa Jerman methodicay yang artinya ajaran tentang metode. Dalam bahasa Yunani kata metode merupakan akar dari kata methodos yang memiliki arti jalan yang dalam bahasa arab disebut thariq. 25

Metode ialah tata urutan kerja yang tersistem untuk memudahkan melakukan suatu kegiatan agar mampu memperoleh tujuan yang diinginkan. ${ }^{26}$ Metode dakwah atau yang biasa disebut manhaj al-dakwah adalah cara yang digunakan da'i untuk menyampaikan materi dakwah (Islam). Metode dakwah berperan penting dalam aktivitas dakwah. Apabila metode yang digunakan tidak benar, sekalipun materi yang diberikan berisi hal baik, maka pesan baik itu dapat ditolak. Seorang da'i harus jeli serta bijak dalam menentukan metode, sebab metode sangat mempengaruhi kelancaran serta keberhasilan dakwah. ${ }^{27}$

Wahidin Saputra dalam buku pengantar ilmu dakwah juga mengemukakan bahwa metode dakwah ialah tata cara tertentu yang dilakukan seorang da'i (komunikator) kepada mad'u agar mampu mencapai tujuan berdasarkan hikmah serta kasih sayang. Hal ini bermakna bahwa pendekatan dakwah mesti bertumpu pada pandangan human oriented yang meletakkan penghargaan mulia atas diri manusia. ${ }^{28}$ Samsul Munir Amin mengategorikan dakwah bil qalam dalam pendekatan atau metode dakwah. Pendekatan atau metode dakwah ialah cara-cara yang digunakan dalam menyampaikan dakwah, agar pesan dakwah mudah diterima mad'ü. Amin menyebutkan tiga pendekatan dakwah, antara lain: dakwah bil lisan, dakwah bil qalam, dan dakwah bil hal. ${ }^{29}$

Melalui metode dakwah Bil Qalam, seorang komunikator dalam komunikasi dakwah dapat melakukan komunikasi melalui tulisan yang disebarkan baik melalui media cetak ataupun konvergensi, sehingga mampu memberikan kesempatan para mad'u memilah pesan dakwah sesuai kebutuhan dan kepentingannya. Selain itu, dengan dakwah bil qalam, pesan

\footnotetext{
${ }^{24}$ Asep Syamsul M. Romli, Komunikasi Dakwah Pendekatan... hlm. 15.

25 Wahidin Saputra, "Pengantar Ilmu Dakwah", (Jakarta: Rajawali Pers, 2011), hlm. 242.

${ }^{26}$ Tim, "Kamus Besar Bahasa Indonesia", (Jakarta: Balai Pustaka, 1986), hlm. 649.

${ }^{27}$ Acep Aripudin, "Pengembangan Metode Dakwah", (Jakarta: Rajawali Pers, 2011), hlm. 8.

${ }^{28}$ Wahidin Saputra, Pengantar Ilmu Dakwah... hlm. 243.

${ }^{29}$ Samsul Munir Amin, "Ilmu Dakwah", (Jakarta: Amzah, 2009), hlm. 13.
} 
dakwah dapat dibaca berulang kali, dapat berhenti, atau melanjutkan ketika ingin mendapatkan pemahaman lebih dan mendetail serta idak terikat oleh suatu waktu dalam mencapai khalayaknya. Sehingga dapat memperdalam pemahaman mad'ū.

Dalam komunikasi dakwah melalui Dakwah Bil Qalam, komunikator mengajak komunikan untuk tiga hal, yakni at-taqrīb (memberi motivasi), at-tahdìd (imbauan peringatan), al-iqnā bi al-fikrah (memersuasi dengan pemikiran dan prinsip agama). Sehingga pada akhirnya tercapai perubahan yang lebih baik pada diri mad' $\bar{u}$ atau komunikan. ${ }^{30}$

Misalnya pemberian motivasi melalui tulisan yang memberikan kabar gembira tentang balasan Allah Swt. terhadap hambanya yang beriman, atau tulisan self help yang membangkitkan semangat pembacanya. Imbauan peringatan misalnya tentang pembalasan Allah Swt terhadap hambanya yang musyrik dan munafik, memberi peringatan tentang kebiasaan masyarakat yang tidak sesuai dengan syariah, dan sebagainya. Kemudian, ajakan untuk memersuasi dengan pemikiran dan prinsip agama misalnya memberi pengetahuan keagamaan atau hal-hal yang sifatnya baru tentang sesuatu yang masih minim diketahui oleh masyarakat namun hal tersebut menjadi penting untuk diketahui masyarakat. Karena tulisan bisa membentuk opini publik yang masif (kuat) dan massal (melibatkan khalayak luas).

Hartono A. Jaiz dalam Kasman menjelaskan bahwa dakwah bil qalam digunakan dalam Komunikasi Dakwah untuk melayani kebutuhan masyarakat terhadap informasi Islam, meliputi informasi dari Alquran dan hadis. Berupaya untuk mewujudkan seruan Al-Qur'an secara cermat dengan menggunakan berbagai media cetak untuk mengembalikannya kepada fikrah dan keuniversalannya. Serta menghidupkan dialog-dialog bernuansa sosial, budaya, politik, dan aspek lainnya. ${ }^{31}$

\section{KESIMPULAN}

Dakwah Bil Qalam sebagai sebuah metode komunikasi dakwah mampu memberikan kesempatan para mad'u memilih pesan dakwah yang sesuai kemampuan dan kepentingannya. Selain itu, dengan Dakwah Bil Qalam, pesan dakwah dapat dibaca berulang kali, dapat berhenti, atau melanjutkan ketika ingin mendapatkan pemahaman lebih dan mendetail serta idak terikat oleh suatu waktu dalam mencapai khalayaknya.

Metode Dakwah Bil Qalam memberikan jawaban atas kelemahan pada dakwah yang hanya dilakukan dengan lisan. Dakwah bil lisan yang mempunyai batasan pada jangkauan dan waktu, dapat diatasi dengan dakwah Bil Qalam. Dakwah bil Qalam memungkinkan

${ }^{30}$ Bambang S. Ma'arif, "Komunikasi Dakwah: Paradigma untuk Aksi”, (Bandung: Simbiosa Rekatama Media. 2010), hlm. 161.

31 Suf Kasman, "Jurnalisme Universal: Menelusuri Prinsip-Prisip Dakwah Bil Qalam dalam Alquran", (Jakarta: Teraju. 2004), hlm. 124. 
komunikator dalam suatu komunikasi dakwah menuangkan gagasan dan ide secara mendalam dan menyeluruh melalui tulisan. Sehingga efek yang ditimbulkan dari suatu komunikasi dakwah akan sama dengan yang diharapkan.

\section{DAFTAR RUJUKAN}

Al-Hasjmy, “Dustur Dakwah dalam Al-Qur'an", Jakarta: Bulan Bintang, 1974.

Amin, Samsul Munir. "Ilmu Dakwah", Jakarta: Amzah, 2009.

Aripudin, Acep. "Pengembangan Metode Dakwah", Jakarta: Rajawali Pers, 2011.

Aziz, Moh. Ali. “Ilmu Dakwah”, Jakarta: Kencana, 2004.

Effendi, Onong Uchayana. "Ilmu Komunikasi Teori dan Praktek", Bandung: Remaja Rosdakarya, 2017.

Ilaihi, Wahyu. “Komunikasi Dakwah", Bandung: Remaja Rosdakarya, 2013.

Kasman, Suf, "Jurnalisme Universal: Menelusuri Prinsip-Prisip Dakwah Bil Qalam dalam Alquran", Jakarta: Teraju. 2004.

Komarudin, dkk. "Dakwah dan Konseling Islam", Semarang: PT. Pustaka Rizki Putra, 2008.

Ma'arif, Bambang S. "Komunikasi Dakwah: Paradigma untuk Aksi”, Bandung: Simbiosa Rekatama Media. 2010.

Mardelis. "Metode Penelitian Suatu Pendekatan Proposal", Jakarta: Bumi Aksara, 2004.

Mulyana, Deddy. "Ilmu Komunikasi Suatu Pengantar", Bandung: Remaja Rosdakarya, 2012.

Munir dan Wahyu Ilaihi, "Manajemen Dakwah", Jakarta: Kencana, 2006.

Muriah, Siti. "Metodologi Dakwah Kontemporer", Yogyakarta: Mitra Pustaka. 2000.

Rakhmat, Jalaluddin. "Psikologi Komunikasi", Bandung : PT Remaja Rosda Karya, 2017.

Rohim, Syaiful. "Teori Komunikasi: Perspektif, Ragam dan Aplikasi”, Jakarta: PT Rineka Cipta, 2009.

Romli, Asep Syamsul M. "Jurnalistik Dakwah: Visi dan Misi Dakwah Bil Qalam", Bandung: Remaja Rosdakarya, 2003.

Romli, Asep Syamsul M. “Komunikasi Dakwah Pendekatan Praktis”, Bandung: Simbiosa Rekatama Media, 2013.

Ruben, Brant D., dan Lea P. Stewart, "Komunikasi Dan Perilaku Manusia”, Jakarta: Rajawali Pers, 2013.

Saputra, Wahidin. "Pengantar Ilmu Dakwah", Jakarta: Rajawali Pers, 2011.

Sholeh, Rosyad. “Manajemen Dakwah Islam”, Yogyakarta: Suara Muhammadiyah, 2010. 
th JURNAL ILMIAH SYIAR

(15) Jurusan Dakwah, FUAD, IAIN Bengkulu

Suparta, Munzier., dan Harjani Hefni, “Metode Dakwah”, Jakarta: Kencana, 2003.

Tim, “Kamus Besar Bahasa Indonesia”, Jakarta: Balai Pustaka, 1986.

Wachid, Abdul. “Wacana Dakwah Kontemporer”, Yogyakarta: Pustaka Pelajar, 2005. 